\title{
Unidirectional Transfer of Prostaglandin Endoperoxides between Platelets and Endothelial Cells
}

\author{
Andrew I. Schafer, Dudley D. Crawford, \\ and Michael A. Gimbrone, Jr. \\ Hemostasis Unit, Hematology Division, Department of Medicine, \\ and the Vascular Pathophysiology Laboratory, Department of \\ Pathology, Brigham and Women's Hospital, and the \\ Departments of Medicine and Pathology, Harvard Medical \\ School, Boston, Massachusetts 02115
}

bstract. An important determinant of plateletvessel wall interactions is the local balance of production of endothelial prostacyclin ( $\left.\mathrm{PGI}_{2}\right)$ and platelet thromboxane (TX) $A_{2}$, labile eicosanoids with opposing effects on hemostasis. Disputed evidence suggests that plateletderived prostaglandin endoperoxide intermediates may be utilized as substrates for vascular $\mathrm{PGI}_{2}$ synthesis. Using several different approaches, we have found that platelets can transfer endoperoxides to cultured endothelial cells for efficient conversion to $\mathrm{PGI}_{2}$, but a reciprocal transfer of endothelial endoperoxides for utilization by platelet thromboxane synthetase does not occur under the same experimental conditions. However, platelets can utilize arachidonic acid released by endothelial cells for lipoxygenase metabolism. We have directly demonstrated the production of $\left[{ }^{3} \mathrm{H}\right] 6-$ keto-PGF ${ }_{1 \alpha}$ (the breakdown product of $\left.\left[{ }^{3} \mathrm{H}\right] \mathrm{PGI}_{2}\right)$ by aspirin-treated endothelial cells in the presence of platelets stimulated with $\left[{ }^{3} \mathrm{H}\right]$ arachidonic acid. In coincubation experiments using either arachidonate or ionophore A23187 as a stimulus, radioimmunoassay of the net production of arachidonic acid metabolites showed that 6-keto-PGF ${ }_{1 \alpha}$ generation by aspirin-treated endothelial cells in the presence of platelets may actually exceed its generation by uninhibited endothelial cells alone. In functional assays, platelet aggregation was inhibited in the presence of aspirin-treated endothelial cells after stimulation with either arachidonate or ionophore

Dr. Schafer is an Established Investigator of the American Heart Association.

Received for publication 20 September 1983 and in revised form 22 December 1983.

J. Clin. Invest.

(c) The American Society for Clinical Investigation, Inc. 0021-9738/84/04/1105/08 \$1.00

Volume 73, April 1984, 1105-1112
A23187. In contrast, the inverse experiments, using aspirin-treated platelets and uninhibited endothelial cells, failed to demonstrate platelet utilization of endothelial endoperoxides for $\mathrm{TXA}_{2}$ production by any of the above methods. These studies thus provide evidence that efficient unidirectional transfer and utilization of platelet-derived endoperoxides for endothelial $\mathrm{PGI}_{2}$ production can occur. This process may serve to amplify $\mathrm{PGI}_{2}$ generation adjacent to areas of vascular injury and permit tight localization of platelet plug formation at these sites.

\section{Introduction}

Stimulated vascular endothelial cells and circulating platelets release free arachidonic acid from their membrane phospholipid pools and rapidly oxygenate it to form the labile prostaglandin $(\mathrm{PG})^{1}$ endoperoxides, $\mathrm{PGG}_{2}$ and $\mathrm{PGH}_{2}$, via the aspirin-inhibitable enzyme cyclooxygenase. Platelets also oxygenate arachidonic acid to form hydroperoxy- and hydroxy-fatty acids via the lipoxygenase pathway, which is not blocked by aspirin. The endoperoxides of endothelial cells and platelets serve as substrates for the enzymatic formation of two labile eicosanoids of extremely potent but completely opposing biologic effects, prostacyclin $\left(\mathrm{PGI}_{2}\right)$ and thromboxane (TX) $\mathrm{A}_{2}\left(\mathrm{TXA}_{2}\right)$. Endothelial $\mathrm{PGI}_{2}$ synthetase converts $\mathrm{PGH}_{2}$ to $\mathrm{PGI}_{2}$, which promotes blood fluidity by acting as a vasodilator and inhibitor of platelet aggregation. Platelet thromboxane synthetase converts $\mathbf{P G H}_{2}$ to $\mathrm{TXA}_{2}$, which promotes hemostasis by acting as a vasoconstrictor and inducer of platelet aggregation. The dynamic balance of production of vascular $\mathrm{PGI}_{2}$ and platelet $\mathrm{TXA}_{2}$ (which are rapidly broken down to their inactive stable metabolites, 6-keto-PGF $F_{1 \alpha}$ and $\mathrm{TXB}_{2}$, respectively) is an important determinant of the state of platelet-vessel wall interactions and primary hemostasis $(1-5)$.

1. Abbreviations used in this paper: BAEC, bovine aortic endothelial cell; DME, Dulbecco's Modified Eagle's medium; HPLC, high performance liquid chromatography; $\mathrm{PG}$, prostaglandin; $\mathbf{P G I}_{2}$, prostacyclin; PRP, platelet-rich plasma; TX, thromboxane. 
Bunting and associates (6) originally proposed that plateletderived prostaglandin endoperoxides can be transferred to the vessel wall and utilized by endothelial cells as exogenous substrate for $\mathrm{PGI}_{2}$ synthesis. This mechanism could serve to limit platelet aggregation at sites of vascular injury by shifting the balance locally to preferential synthesis of $\mathrm{PGI}_{2}$. Production of vascular $\mathrm{PGI}_{2}$ from platelet-derived endoperoxides has been confirmed by some (7) but not by other (8-10) laboratories. This study was designed to investigate the intercellular transfer and utilization of arachidonic acid and its metabolites between platelets and endothelial cells. We have examined in detail the transfer of endoperoxides from platelets to cultured endothelial cells and the possible reverse transfer of endoperoxides from endothelial cells to platelets. The latter phenomenon is potentially of considerable physiologic and pharmacologic importance, because it would tend to offset any platelet-to-endothelial transfer of endoperoxides and could permit continued platelet $\mathrm{TXA}_{2}$ production in aspirin-treated subjects.

\section{Methods}

Materials. $\left[{ }^{3} \mathrm{H}\right]$ Arachidonic acid $(83.9 \mathrm{Ci} / \mathrm{mmol}),\left[{ }^{3} \mathrm{H}\right] \mathrm{TXB} \mathrm{B}_{2}(100-150$ $\mathrm{Ci} / \mathrm{mmol})$, and $\left[{ }^{3} \mathrm{H}\right] 6-\mathrm{keto}-\mathrm{PGF}_{1 \alpha}(120.0 \mathrm{Ci} / \mathrm{mmol})$ were obtained from New England Nuclear (Boston, MA); TXB $_{2}$ antiserum from The Upjohn Co. (Kalamazoo, MI); 6-keto-PGF ${ }_{1 \alpha}$ antiserum from Seragen Inc. (Boston, MA); sodium arachidonate from Nu-Chek-Prep., Inc. (Elysian, MN); Dulbecco's Modified Eagle's Medium and Dulbecco's phosphate-buffered saline from M. A. Bioproducts (Walkersville, MD); ionophore A23187 from Calbiochem-Behring Corp. (San Diego, CA); acetylsalicylic acid (aspirin) and tranylcypromine from Sigma Chemical Co. (St. Louis, MO).

Endothelial cell cultures. Bovine aortic endothelial cells (BAEC) were isolated from the intimal lining of the thoracic aorta of yearling calves by a modification of published techniques $(11,12)$ and characterized by morphological, immunologic, and biochemical criteria, as previously described $(11,12)$. A strain of these cells $(11-\mathrm{BAEC})$ was grown to confluency in Dulbecco's Modified Eagle's Medium (DME) containing $10 \%$ calf serum and used in subculture passages $2-25$. In experiments requiring aspirin pretreatment of the BAEC, cell monolayers were washed three times with fresh DME, incubated with $0.5 \mathrm{mM}$ aspirin in DME at $37^{\circ}$ for $1 \mathrm{~h}$, and then washed again with fresh DME.

Platelet preparations. Venous blood anticoagulated with $13.5 \%$ acid citrate dextrose (National Institutes of Health Formula A) was centrifuged at $160 \mathrm{~g}$ for $10 \mathrm{~min}$ to obtain platelet-rich plasma (PRP). For preparation of washed platelet suspensions, PRP was adjusted to $\mathrm{pH} 6.5$ with additional acid citrate dextrose, centrifuged at $1,500 \mathrm{~g}$ for $10 \mathrm{~min}$, the platelet pellet washed in buffer containing $8 \mathrm{mM} \mathrm{Na}_{2} \mathrm{HPO}_{4}, 2 \mathrm{mM}$ $\mathrm{NaH}_{2} \mathrm{PO}_{4}, 5 \mathrm{mM} \mathrm{KCl}, 135 \mathrm{mM} \mathrm{NaCl}$, and $10 \mathrm{mM}$ ethylenediaminetetraacetate, $\mathrm{pH} 7.4$, and finally resuspended in a modified Tyrode's buffer containing $130 \mathrm{mM} \mathrm{NaCl}, 9 \mathrm{mM}$ sodium bicarbonate, $6 \mathrm{mM}$ dextrose, $10 \mathrm{mM}$ sodium citrate, $10 \mathrm{mM}$ Trizma base, $0.8 \mathrm{mM} \mathrm{KH}_{2} \mathrm{PO}_{4}$ $3 \mathrm{mM} \mathrm{KCl}$, and $0.9 \mathrm{mM} \mathrm{MgCl}_{2}, \mathrm{pH}$ 7.3. Platelet counts were determined in a model F Coulter Counter (Coulter Electronics Inc., Hialeah, FL) For experiments requiring aspirin pretreatment of the platelets, donors ingested $650 \mathrm{mg}$ aspirin $1 \mathrm{~h}$ before blood donation or PRP was incubated with $0.5 \mathrm{mM}$ aspirin at $25^{\circ} \mathrm{C}$ for $30 \mathrm{~min}$. To monitor the presence or absence of aspirin effect, PRP was prepared simultaneously from blood anticoagulated with $13 \mathrm{mM}$ sodium citrate, and aggregation in response to $0.5 \mathrm{mM}$ sodium arachidonate was monitored. Platelet aggregation studies were performed using a standard nephelometric technique (13) in which 0.4-ml aliquots of PRP, washed platelets, or mixtures of washed platelets and suspensions of endothelial cells were stirred at $37^{\circ} \mathrm{C}$ in a Payton dual-channel aggregometer (Payton Associates, Inc., Buffalo, NY).

Experimental design. Experiments to examine the transfer of arachidonic acid and prostaglandin endoperoxides released from endogenous endothelial cell membrane phospholipid pools to platelets were designed as follows. Monolayers of BAEC in $10 \mathrm{~cm}$ petri dishes were washed three times with fresh DME and then incubated with $10 \mu \mathrm{Ci}$ $\left[{ }^{3} \mathrm{H}\right]$ arachidonic acid in $5 \mathrm{ml}$ Dulbecco's phosphate-buffered saline (PBS) for $75 \mathrm{~min}$ at $37^{\circ} \mathrm{C}$ in a rocking water bath. Unincorporated $\left[{ }^{3} \mathrm{H}\right]$ arachidonic acid was then removed by two 5 -ml rinses with Dulbecco's PBS, pH 7.4. $\sim 90 \%$ of the radioactivity remained endothelial cell-associated. We have previously shown (14) that this radioactivity partitioned with phospholipids after extraction with chloroform:methanol (3:1). Washed, aspirin-pretreated platelet suspensions, or buffer blanks, were layered over the washed monolayers of endothelial cells, and the release of $\left[{ }^{3} \mathrm{H}\right]$ arachidonic acid was initiated with $8 \mu \mathrm{M}$ ionophore A23187. We have previously shown that $<1 \%$ endothelial cells lyse under these conditions (14). The reactions were terminated at $5 \mathrm{~min}$ by suctioning off the supernatants. The supernatants were immediately acidified to pH 3.0 with $2.7 \mathrm{M}$ citric acid, and extracted twice with ethyl acetate in preparation for high performance liquid chromatography (HPLC) analysis.

In other experiments, transfer of prostaglandin endoperoxides between endothelial cells and platelets was studied by stimulating mixed suspensions of the two cell types with the direct substrate, $\left[{ }^{3} \mathrm{H}\right]$ arachidonic acid. After washing monolayers of BAEC with fresh PBS as described above, the monolayers were incubated at $4^{\circ} \mathrm{C}$ for 15 min with $0.02 \%$ ethylenediaminetetraacetate, then gently scrape-harvested with a rubber policeman, and washed with and resuspended in Dulbecco's PBS, pH 7.4. Suspensions of washed endothelial cells (with or without aspirin pretreatment) and washed platelets (with or without aspirin pretreatment) were mixed in a final volume of $1 \mathrm{ml}$ and stirred at $37^{\circ} \mathrm{C}$. The cell suspensions were stimulated by adding $\left[{ }^{3} \mathrm{H}\right]$ arachidonic acid $(2 \mu \mathrm{Ci}$, final concentration of $10 \mu \mathrm{M})$. Reactions were terminated, acidified, and extracted with ethyl acetate, as described above, for HPLC analysis.

Experiments were also performed to quantitate endothelial and platelet arachidonic acid metabolites, 6-keto-PGF ${ }_{1 \alpha}$ and $\mathrm{TXB}_{2}$, respectively. Stirred suspensions of the two cell types, with or without aspirin pretreatment in various combinations, were stimulated with either 1 $\mu \mathrm{M}$ ionophore $\mathrm{A} 23187$ or $50 \mu \mathrm{M}$ sodium arachidonate. After $5 \mathrm{~min}$ of incubation at $37^{\circ} \mathrm{C}$, reaction mixtures were immediately microfuged in a Beckman microfuge (Beckman Instruments, Inc., Spinco Div., Palo Alto, $\mathrm{CA}$ ) at $8,700 \mathrm{~g}$ for $2 \mathrm{~min}$ and supernatants removed for radioimmunoassay of $\mathrm{TXB}_{2}$ and 6-keto-PGF $\mathrm{PG}_{1 \alpha}$.

$H P L C$. Pooled ethyl acetate extracts of terminated reactions were evaporated under $\mathrm{N}_{2}$, and the samples were injected in $50 \mu \mathrm{l}$ of methanol into a $4.6 \times 250 \mathrm{~mm}$ Ultrasphere ODS $5-\mu \mathrm{m}$ reverse-phase HPLC column (Altex Scientific Inc., Berkeley, CA). Separations were performed as previously described (15), using increasing proportions of acetonitrile $(30.5-95 \%)$ in aqueous phosphoric acid (pH 2.0). The flow rate was 1 $\mathrm{ml} / \mathrm{min}$. The column was equilibrated at $30.5 \%$ acetonitrile for $\mathbf{4 0} \mathrm{min}$ before reuse. A Beckman model 110A single-pump HPLC with a PerkinElmer (Norwalk, CT) LC-75 variable-wavelength spectrophotometer detector was used, and arachidonic acid metabolites were measured by absorbance at $192 \mathrm{~nm}$ and collection of $1.0 \mathrm{ml}$ fractions for radioactivity. Nonradioactive standards were run simultaneously; $\mathrm{TXB}_{2}$, prostaglandins 
$F_{2 \alpha}, E_{2}$, and $D_{2}$, and 12-hydroxy-5,8,10,14-eicosatetraenoic acid (12HETE) were provided by Dr. John Pike, The Upjohn Co. (Kalamazoo, $\mathrm{MI})$.

Radioimmunoassays. After appropriate dilutions, the amount of $\mathrm{TXB}_{2}$ and 6-keto-PGF ${ }_{1 \alpha}$ in supernatants of microfuged samples was determined by standard radioimmunoassay with phosphate-gelatin buffer ( $50 \mathrm{mM}$ potassium biphosphate, $0.14 \mathrm{M}$ sodium chloride, and $0.1 \%$ gelatin, $\mathrm{pH}$ 7.4), a 1:2,000 dilution of antibody, and 10,000-dpm $\left[{ }^{3} \mathrm{H}\right] \mathrm{TXB}_{2}$ or $\left[{ }^{3} \mathrm{H}\right] 6-k e t o-\mathrm{PGF}_{1 \alpha}$. After overnight incubation at $4^{\circ} \mathrm{C}$ charcoal-coated dextran was used to separate bound from unbound radioactivity. Cross-reactivities of the anti-TXB ${ }_{2}$ antibody with 6-keto$\mathrm{PGF}_{1 \alpha}$ and of the anti-6-keto-PGF ${ }_{1 \alpha}$ antibody with $\mathrm{TXB}_{2}$ were both $<0.1 \%$. The assays are sensitive to $50 \mathrm{pg} / \mathrm{ml} \mathrm{TXB}_{2}$ and $200 \mathrm{pg} / \mathrm{ml} \mathrm{6-}$ keto-PGF ${ }_{1 \alpha}$, respectively.

\section{Results}

In order to examine the ability of endothelial cells to transfer prostaglandin endoperoxides to platelets, monolayers of endothelial cells were labeled with $\left[{ }^{3} \mathrm{H}\right]$ arachidonic acid, as described in Methods, washed to remove unincorporated $\left[{ }^{3} \mathrm{H}\right]$ arachidonic acid, and then stimulated with calcium ionophore A23187 in the presence or absence of aspirin-treated and washed platelet suspensions. Any radioactive products of these reactions, separated by HPLC, must be derived from phospholipid pools of endothelial origin. As shown in Fig. 1, radiolabeled endothelial cells, incubated by themselves, released $\left[{ }^{3} \mathrm{H}\right] 6-$ ketoPGF $_{1 \alpha}$ (the breakdown product of $\left[{ }^{3} \mathrm{H}\right] \mathrm{PGI}_{2}$ ) and unconverted $\left[{ }^{3} \mathrm{H}\right]$ arachidonic acid in response to ionophore stimulation. When the prelabeled endothelial cells were stimulated with ionophore in the presence of unlabeled, aspirin-treated platelets, large amounts of $\left[{ }^{3} \mathrm{H}\right] 12$-HETE, the major platelet lipoxygenase metabolite, were released in addition to $\left[{ }^{3} \mathrm{H}\right] 6-$ keto- $\mathrm{PGF}_{1 \alpha}$ and $\left[{ }^{3} \mathrm{H}\right]$ arachidonic acid. No radiolabeled platelet cyclooxygenase products $\left(\mathrm{TXB}_{2}\right.$ or prostaglandins) were detected in this reaction. These results indicate that endothelial cells can transfer arachidonic acid to aspirin-treated platelets to be metabolized by the uninhibited lipoxygenase pathway. However, endothelial cells apparently could not transfer endoperoxides to platelets for metabolism to thromboxane and prostaglandins, under these experimental conditions.

The experiments above showed failure of platelet utilization of prostaglandin endoperoxides derived from arachidonic acid liberated from endogenous endothelial cell membrane phospholipid pools by calcium ionophore. We next examined the ability of endothelial endoperoxides generated directly from exogenous arachidonic acid substrate to be utilized for platelet thromboxane synthesis. In these experiments, suspensions of endothelial cells and aspirin-pretreated platelets were coincubated, continuously stirred at $37^{\circ} \mathrm{C}$, and directly stimulated with $\left[{ }^{3} \mathrm{H}\right]$ arachidonate $(2 \mu \mathrm{Ci}, 10 \mu \mathrm{M}$ final concentration). In separate experiments, it was determined that this concentration of arachidonate causes $<3 \%$ lysis of platelets. Any $\left[{ }^{3} \mathrm{H}\right] \mathrm{TXB}_{2}$ generated in this reaction presumably would be produced from endoperoxides transferred from endothelial cells to platelets. As shown in Fig. $2 A$, essentially no $\left[{ }^{3} \mathrm{H}\right] \mathrm{TXB}_{2}$ synthesis occurred,

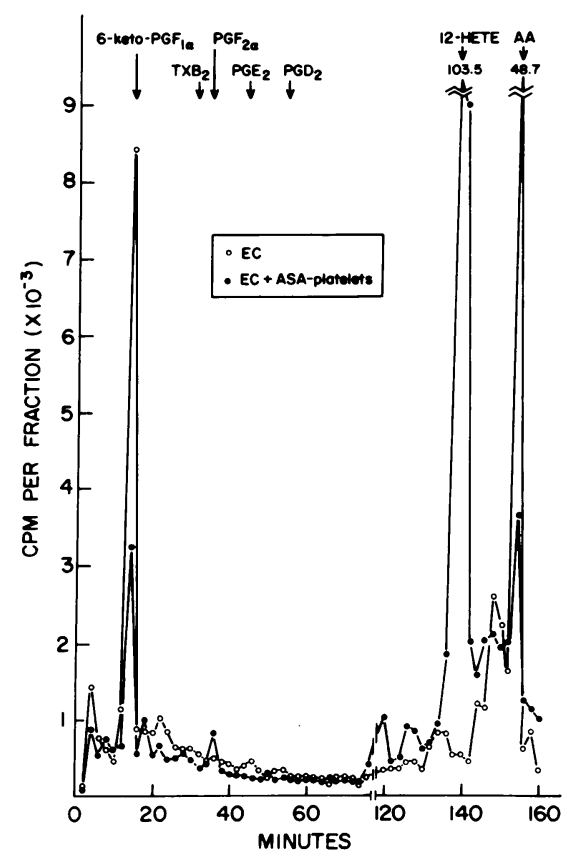

Figure 1. HPLC analysis of arachidonic acid metabolites produced by stimulation of endothelial cells with ionophore A23187 in the presence or absence of aspirin-treated platelets. Monolayers of BAEC (5 $\times 10^{6}$ cells per assay), prelabeled with $\left[{ }^{3} \mathrm{H}\right]$ arachidonic acid $(10 \mu \mathrm{Ci})$, were overlaid with aspirin-treated and washed platelet suspensions $\left(12 \times 10^{8}\right.$ cells in $\left.5 \mathrm{ml}\right)$ or platelet-free buffer $(5 \mathrm{ml})$. After stimulation with ionophore $\mathrm{A} 23187$ for $5 \mathrm{~min}$ at $37^{\circ} \mathrm{C}$, samples were extracted and prepared for HPLC as described in Methods. Retention times of nonradioactive standards of arachidonic acid metabolites, added to the HPLC injection samples, are marked at the top.

despite the production of large amounts of $\left[{ }^{3} \mathrm{H}\right] 6-$ keto- $^{-} \mathrm{PGF}_{1 \mathrm{c}}$ by the uninhibited endothelial cells. In contrast, the products of the inverse experiment, in which a mixture of aspirin-treated endothelial cells and uninhibited platelets was stimulated with $\left[{ }^{3} \mathrm{H}\right]$ arachidonate under the same conditions, are shown in Fig. $2 \mathrm{~B}$. The $\left[{ }^{3} \mathrm{H}\right] 6-$ keto- $\mathrm{PGF}_{1 \alpha}$ peak represents conversion of platelet-derived endoperoxide by endothelial $\mathrm{PGI}_{2}$ synthetase.

The apparent unidirectional transfer of endoperoxides from platelets to endothelial cells, but not from endothelial cells to platelets, was further examined in functional studies. As shown in Fig. 3, uninhibited washed platelets fully aggregated in response to $50 \mu \mathrm{M}$ arachidonate. Aggregation was completely abolished when these platelets were stimulated by arachidonate in the presence of suspensions of endothelial cells, presumably due to the inhibitory effect of $\mathrm{PGI}_{2}$ produced by the endothelial cells. Aggregation was still completely inhibited, however, when aspirin-treated endothelial cells were used in the incubation with the platelets, thus suggesting that sufficient platelet-derived endoperoxides were transferred to support endothelial prostacyclin production. Aspirin-treated endothelial cells likewise al- 


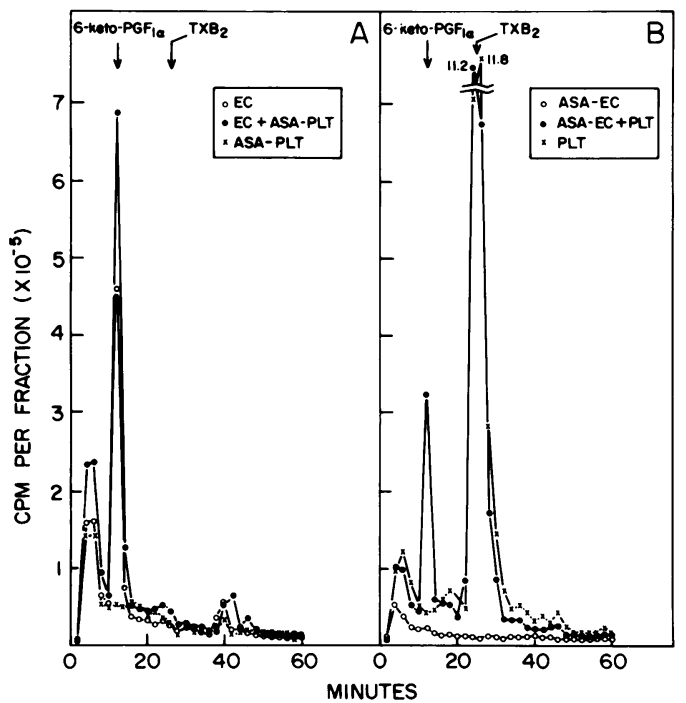

Figure 2. HPLC analysis of $\left[{ }^{3} \mathrm{H}\right] 6-$ keto- $\mathrm{PGF}_{1 \alpha}$ and $\left[{ }^{3} \mathrm{H}\right] \mathrm{TXB}_{2}$ produced in mixed suspensions of endothelial cells and platelets stimulated with $\left[{ }^{3} \mathrm{H}\right]$ arachidonic acid. $(A)$ Endothelial cells alone (O), endothelial cells + aspirin-treated platelets $(\bullet)$, or aspirin-treated platelets alone $(x)$ were stimulated with $\left[{ }^{3} \mathrm{H}\right]$ arachidonate $(2 \mu \mathrm{Ci}$, final concentration of $10 \mu \mathrm{M}$ ) for $5 \mathrm{~min}$ in stirred suspensions at $37^{\circ} \mathrm{C}$. Samples were extracted and prepared for HPLC as described in Methods. $(B)$ Same experimental conditions, except that aspirin-treated endothelial cells alone $(0)$, aspirin-treated endothelial cells + platelets $(\bullet)$, or platelets alone $(x)$ were used. Average platelet and endothelial cell counts in each reaction were $1.1 \times 10^{7}$ and $5.6 \times 10^{7}$, respectively (approximately 5:1 ratio).

most completely inhibited the aggregation of platelets induced by ionophore A23187 (not shown). In the converse experiment, aspirin-treated platelets did not aggregate in response to arachidonate in the presence of endothelial cells, even when platelet:endothelial cell ratios in the coincubation were widely varied (500:1 to 1:1). Furthermore, aspirin-treated platelets also did not aggregate in the presence of endothelial cells when endothelial $\mathrm{PGI}_{2}$ synthetase was inhibited by tranylcypromine $(16,17)$. Under the conditions of this experiment, we found $72 \%$ inhibition of endothelial $\mathrm{PGI}_{2}$ synthesis by tranylcypromine, as measured by radioimmunoassay of 6-keto-PGF ${ }_{1 \alpha}$. Aspirin-treated platelets did, however, aggregate comparably in the presence or absence of aspirin-treated endothelial cells in response to thrombin (1 $\mathrm{U} / \mathrm{ml}$ ) or collagen, agents which can stimulate platelet aggregation independent of thromboxane production (data not shown). These studies therefore showed that insufficient, if any, endoperoxides of endothelial origin can be utilized by platelets to induce aggregation when endogenous platelet endoperoxide production is blocked with aspirin.

To provide a more quantitative analysis of the net result of this apparent preferential transfer of endoperoxides from platelets to endothelial cells, mixed suspensions of endothelial cells and/ or platelets, pretreated with aspirin in various combinations, were stimulated with arachidonate $(50 \mu \mathrm{M})$ or ionophore $\mathrm{A} 23187$ $(1 \mu \mathrm{M})$, and the amount of $\mathrm{TXB}_{2}$ and 6-keto-PGF $\mathrm{PG}_{1 \alpha}$ produced was determined by radioimmunoassay. The results are summarized in Table I. As shown in Table I, Section $A$, endoperoxides from uninhibited platelets were efficiently utilized by aspirin-pretreated endothelial cells for the generation of 6-ketoPGF $_{1 \alpha}$. In fact, in some cases, the amount of 6-keto-PGF produced by aspirin-treated endothelial cells in the presence of platelets exceeded that produced by uninhibited endothelial cells alone. This effect was observed both with arachidonate and ionophore A23187 as stimuli. In contrast, as shown in Table I, Section $B$, there was no evidence for the "reverse" transfer of endoperoxides from endothelial cells to platelets. Total $\mathrm{TXB}_{2}$

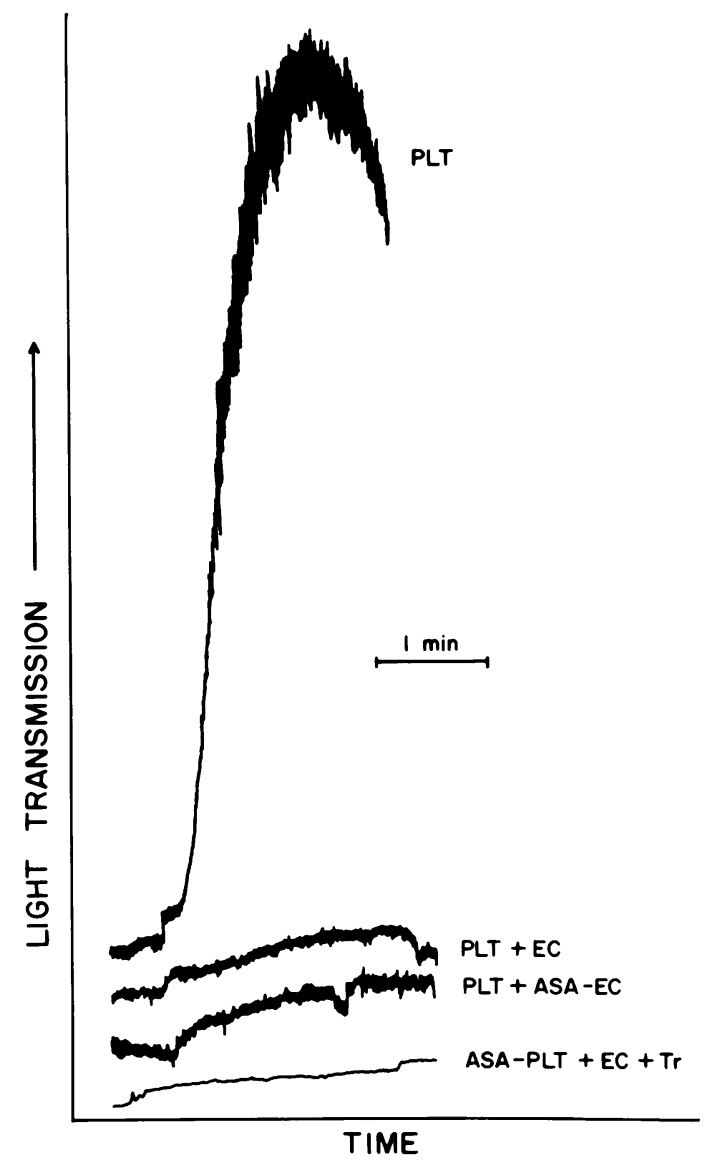

Figure 3. Aggregation of platelets in the absence or presence of endothelial cells. Suspensions of platelets without (PLT) or with aspirin pretreatment (ASA-PLT) were stimulated with $50 \mu \mathrm{M}$ arachidonate in the absence or presence of suspensions of endothelial cells without (EC) or with aspirin pretreatment (ASA-EC). In the bottom tracing, EC were preincubated with tranylcypromine $(\mathrm{Tr}), 500 \mu \mathrm{g} / \mathrm{ml}$, for 2 min before the addition of ASA-PLT and arachidonate. Platelet and endothelial cell counts in each reaction were $8.3 \times 10^{6}$ and 1.7 $\times 10^{6}$, respectively (approximately 5:1 ratio), unless otherwise stated in the text, in a final reaction volume of $0.4 \mathrm{ml}$. 
Table I. Production of 6-Keto-PGF $F_{l \alpha}$ and $T X B_{2}$

\begin{tabular}{|c|c|c|c|c|}
\hline \multicolumn{5}{|c|}{ (A) Transfer of endoperoxides from platelets to endothelial cells } \\
\hline \multirow{2}{*}{$\begin{array}{l}\text { Cell ratios } \\
\text { (platelets:EC) }\end{array}$} & \multicolumn{2}{|c|}{ Stimulus: arachidonate } & \multicolumn{2}{|c|}{ Stimulus: ionophore A23187 } \\
\hline & Cell mixture & 6-keto-PGF $F_{1 a}$ & Cell mixture & 6-keto-PGF 1 ia \\
\hline & & $n g / m l$ & & $n g / m l$ \\
\hline & EC & $57.00 \pm 2.00$ & EC & $21.00 \pm 4.00$ \\
\hline \multirow[t]{3}{*}{$1: 1$} & Plt & $0.64 \pm 0.04$ & Plt & $0.14 \pm 0.03$ \\
\hline & ASA-EC & $0.21 \pm 0.02$ & ASA-EC & $0.05 \pm 0.02$ \\
\hline & Plt + ASA-EC & $41.00 \pm 8.00$ & PIt + ASA-EC & $6.60 \pm 0.12$ \\
\hline \multirow[t]{3}{*}{$5: 1$} & Plt & $1.88 \pm 0.02$ & Plt & $0.85 \pm 0.03$ \\
\hline & ASA-EC & $0.21 \pm 0.02$ & ASA-EC & $0.05 \pm 0.02$ \\
\hline & Plt + ASA-EC & $167.00 \pm 21.00$ & PIt + ASA-EC & $22.40 \pm 0.30$ \\
\hline \multicolumn{5}{|c|}{ (B) Transfer of endoperoxides from endothelial cells to platelets } \\
\hline \multirow{4}{*}{$\begin{array}{l}\text { Cell ratios } \\
\text { (platelets:EC) }\end{array}$} & \multicolumn{2}{|c|}{ Stimulus: arachidonate } & \multicolumn{2}{|c|}{ Stimulus: ionophore A23187 } \\
\hline & Cell mixture & $\mathrm{TXB}_{2}$ & Cell mixture & $\mathrm{TXB}_{2}$ \\
\hline & & $n g / m l$ & & $n g / m l$ \\
\hline & $\mathrm{EC}$ & $0.97 \pm 0.02$ & EC & $0.76 \pm 0.15$ \\
\hline \multirow[t]{3}{*}{$1: 1$} & Plt & $3.50 \pm 0.42$ & Plt & $4.60 \pm 1.40$ \\
\hline & ASA-Plt & $0.37 \pm 0.06$ & ASA-Plt & 0 \\
\hline & EC + ASA-Plt & $1.08 \pm 0.13$ & EC + ASA-Plt & $1.48 \pm 0.09$ \\
\hline \multirow[t]{3}{*}{$5: 1$} & Plt & $34.80 \pm 6.60$ & Plt & $22.60 \pm 2.60$ \\
\hline & ASA-PIt & $0.47 \pm 0.11$ & ASA-Plt & $0.14 \pm 0.02$ \\
\hline & $\mathrm{EC}+\mathrm{ASA}-\mathrm{Plt}$ & $1.52 \pm 0.02$ & EC + ASA-Plt & $2.16 \pm 0.15$ \\
\hline \multirow[t]{3}{*}{ 500:1 } & Plt & $654.00 \pm 26.00$ & Plt & $29.10 \pm 1.10$ \\
\hline & ASA-Plt & $1.48 \pm 0.09$ & ASA-PIt & 0 \\
\hline & EC + ASA-PIt & $2.35 \pm 0.11$ & EC + ASA-Plt & $0.82 \pm 0.13$ \\
\hline
\end{tabular}

Production of 6-keto-PGF ${ }_{1 \alpha}$ and $\mathrm{TXB}_{2}$, measured by radioimmunoassay, in stirred suspensions of endothelial cells (EC) and platelets (plt), alone or mixed in different cell:cell ratios, with various combinations of aspirin pretreatment of the cells. Incubations were carried out at $37^{\circ} \mathrm{C}$ in a final reaction volume of $1 \mathrm{ml}$, and were terminated after $5 \mathrm{~min}$ after stimulation with arachidonate $(50 \mu \mathrm{M})$ or ionophore $\mathrm{A} 23187(1 \mu \mathrm{m})$. Values shown are means \pm SEM of triplicate determinations representing three experiments. Plt $=$ untreated platelets; EC $=$ untreated endothelial cells; ASA-plt = aspirin-treated platelets; ASA-EC = aspirin-treated endothelial cells.

production by aspirin-treated platelets in the presence of uninhibited endothelial cells was no greater than the sum of the amounts of $\mathrm{TXB}_{2}$ produced independently by each (Table I, Section $B$ ), or by aspirin-treated platelets and aspirin-treated endothelial cells together (data not shown). Again, this effect was observed both with arachidonate and ionophore A23187 as stimuli. Evidence of endothelial-to-platelet endoperoxide transfer was not detected even when the platelet:endothelial cell count ratio was greatly increased to $500: 1$.

Table II reinterprets these data to show the balance of the net production of the two opposing eicosanoids. The ratios of 6-keto-PGF ${ }_{1 \alpha} / \mathrm{TXB}_{2}$ or $\mathrm{TXB}_{2} / 6-$ keto-PGF $_{1 \alpha}$ produced in response to arachidonate stimulation are indicated. Table II, Sec- tion $A$ demonstrates that, at platelet:endothelial cell ratios of $1: 1$ and 5:1, utilization of platelet-derived endoperoxides by aspirin-treated endothelial cells is so efficient that the balance of production actually favors the synthesis of $\mathrm{PGI}_{2}$ over $\mathbf{T X A _ { 2 }}$. This transfer of platelet-generated endoperoxides to endothelial cells does not occur, however, at the expense of platelet $\mathrm{TXB}_{2}$ production: $\mathrm{TXB}_{2}$ production by platelets in the presence of aspirin-treated endothelial cells is no less than $\mathrm{TXB}_{2}$ production by the same number of platelets alone. In contrast, as shown in Table II, Section $B$, the failure of endothelial-derived endoperoxides to be utilized by platelets for thromboxane synthesis is reflected in the very low ratios of $\mathrm{TXB}_{2} / 6-$ keto-PGF $\mathrm{PG}_{1 \alpha}$.

In order to test the possibility that the failure of endoperoxides 
Table II. Balance of Net Production of 6-Keto-PGF $F_{1 \alpha}$ and TXB

(A) Transfer of endoperoxides from platelets to endothelial cells

\begin{tabular}{|c|c|c|c|}
\hline \multirow{2}{*}{$\begin{array}{l}\text { Cell ratios } \\
\text { (Plt:ASA-EC) }\end{array}$} & \multirow{2}{*}{$\frac{\text { 6-keto-PGF }}{\mathrm{TXB}_{2}}$} & \multicolumn{2}{|c|}{$\mathrm{TXB}_{2}$} \\
\hline & & Plt + buffer & Plt + ASA-EC \\
\hline & & $n g / m l$ & \\
\hline $1: 1$ & 6.84 & $3.50 \pm 0.42$ & $5.90 \pm 0.40$ \\
\hline $5: 1$ & 4.76 & $34.80 \pm 6.60$ & $34.70 \pm 8.70$ \\
\hline $500: 1$ & 0.01 & $654.00 \pm 26.00$ & $513.00 \pm 12.00$ \\
\hline
\end{tabular}

(B) Transfer of endoperoxides from endothelial cells to platelets

\begin{tabular}{lllll}
\hline & & \multicolumn{2}{c}{ 6-keto-PGF ${ }_{1 a}$} \\
\cline { 5 - 5 } $\begin{array}{l}\text { Cell ratios } \\
\text { (ASA-Plt:EC) }\end{array}$ & 6-keto-PGF & & EC + buffer & EC + ASA-plt \\
\hline & & $n g / m l$ & \\
$1: 1$ & 0.005 & & $57.00 \pm 2.00$ & $24.00 \pm 2.00$ \\
$5: 1$ & 0.019 & & $57.00 \pm 2.00$ & $29.00 \pm 2.00$ \\
$500: 1$ & 0.043 & $57.00 \pm 2.00$ & $32.00 \pm 2.00$
\end{tabular}

Balance of net production of 6-keto-PGF ${ }_{1 \alpha}$ and $\mathrm{TXB}_{2}$ in response to $50 \mu \mathrm{M}$ arachidonate stimulation. Experimental conditions as in Table I. Corresponding values for 6-keto-PGF ${ }_{1 \alpha}$ in $(A)$ and for $\mathrm{TXB}_{2}$ in $(B)$ at each cell-cell ratio are listed in Table $I$.

generated by endothelial cells to be utilized by platelets is due to an inability of endothelial-derived endoperoxides to penetrate cell membranes, intact cells, and cells disrupted by freeze-thaw lysis were incubated together in various combinations. As shown in Table III, transfer of endoperoxides from endothelial cells to platelets could not be demonstrated even when either or both cell types were lysed.

\section{Discussion}

This study was designed to investigate the regulation of plateletvessel wall interactions by the intercellular transfer and utilization of arachidonic acid and its metabolites. Our data indicate that cultured endothelial cells are capable of utilizing platelet-derived endoperoxides for $\mathrm{PGI}_{2}$ production very efficiently. In fact, under some circumstances, platelet-dependent $\mathbf{P G I}_{2}$ synthesis by aspirin-treated endothelial cells considerably exceeds the $\mathrm{PGI}_{2}$ synthetic capacity of uninhibited endothelial cells alone (Table I, Section $A$ ). Unlike platelets, which possess a very active cyclooxygenase and can readily convert arachidonic acid to endoperoxides, vascular cyclooxygenase converts arachidonic acid to endoperoxides quite inefficiently (18). Therefore, endoperoxides transferred from platelets may bypass this rate-limiting step in endogenous endothelial $\mathbf{P G I}_{2}$ synthesis and thus serve to amplify vascular $\mathrm{PGI}_{2}$ production.

Although we found evidence for efficient transfer of endoperoxides from platelets to endothelial cells in our in vitro model system, we were unable to demonstrate a reverse transfer process, i.e., from endothelial cells to platelets, under the same experimental conditions. In contrast, arachidonic acid released upon stimulation from endothelial cell membrane phospholipid pools was freely transferred to aspirin-treated platelets and utilized by platelet lipoxygenase for the synthesis of 12-HETE (Fig. 1). A precedent for intercellular arachidonic acid transfer occurs in monocytes, which can utilize arachidonic acid released by $\mathrm{T}$ lymphocytes as substrate for the synthesis of eicosanoids (19). Our finding, which suggests that platelets (and perhaps leukocytes) can utilize endothelial-derived arachidonic acid substrate for the production of lipoxygenase metabolites after chemical or mechanical perturbation of the vessel wall, may represent an important mechanism of vascular stimulation of blood cell arachidonic acid metabolism.

We were interested in examining the reciprocal transfer of endoperoxides from endothelial cells to platelets because, if it were operative, this would tend to offset the endothelial utilization of platelet-derived endoperoxides. Furthermore, because aspirin can have differential inhibitory effects on platelet and endothelial cyclooxygenases (20-22), such an interaction could theoretically permit continued thromboxane production to occur in subjects treated with aspirin, if vascular cyclooxygenase were not completely blocked. Our finding of an apparently unidirectional endoperoxide transfer was confirmed by several ap-

Table III. Effect of Lysis of Cells on Transfer of Endoperoxides from Endothelial Cells to Platelets

\begin{tabular}{lc}
\hline & \multicolumn{1}{c}{$\mathrm{TXB}_{2}$} \\
\hline & $n g / m l$ \\
Cells alone & \\
EC & $1.58 \pm 0.28$ \\
Lysed EC & $1.09 \pm 0.13$ \\
Plt & $25.70 \pm 2.02$ \\
ASA-plt & $0.04 \pm 0.02$ \\
Lysed plt & $35.45 \pm 5.31$ \\
Lysed ASA-plt & 0 \\
Cell mixtures & \\
EC + ASA-plt & $1.56 \pm 0.14$ \\
Lysed EC + ASA-plt & $1.03 \pm 0.21$ \\
EC + lysed ASA-plt & $1.46 \pm 0.02$ \\
Lysed EC + lysed ASA-plt & $1.60 \pm 0.08$ \\
\end{tabular}

Production of $\mathrm{TXB}_{2}$, measured by radioimmunoassay, in stirred suspensions of endothelial cells (EC) and aspirin-treated platelets (ASAplt), alone or in mixture. Where indicated, the cells were lysed by sequential freeze-thawing three times in a dry ice-acetone bath. Reactions were carried out with arachidonate stimulation, as described in Table I. 6-keto- $\mathrm{PGF}_{1 \alpha}$ production by EC alone $=73.86 \pm 11.58 \mathrm{ng} / \mathrm{ml}$; lysed EC alone $=41.42 \pm 8.37 \mathrm{ng} / \mathrm{ml}$. Values are means $\pm S E M$ of triplicate determinations representing two experiments. The ratio of platelets to endothelial cells was 5:1. 
proaches. First, aspirin-treated endothelial cells, which by themselves were incapable of converting $\left[{ }^{3} \mathrm{H}\right]$ arachidonic acid to $\left[{ }^{3} \mathrm{H}\right] 6-k e t o-P G F_{1 \alpha}$, were able to produce $\left[{ }^{3} \mathrm{H}\right] 6-k e t o-P G F_{1 \alpha}$ in the presence of platelets and $\left[{ }^{3} \mathrm{H}\right]$ arachidonic acid. In contrast, $\left[{ }^{3} \mathrm{H}\right] \mathrm{TXB}_{2}$ was not produced by aspirin-treated platelets in the presence of untreated endothelial cells. Second, quantitative analysis by radioimmunoassay of net $\mathrm{TXB}_{2}$ and 6-keto-PGF ${ }_{1 \alpha}$, produced in mixtures of platelets and endothelial cells with various combinations of aspirin pretreatment, corroborated the radiolabel experiments showing unidirectional transfer of endoperoxides from platelets to endothelial cells. Third, functional studies demonstrated sufficient $\mathbf{P G I}_{2}$ release by aspirin-treated endothelial cells in the presence of platelets to completely inhibit platelet aggregation, confirming the observations of Marcus et al. (7). However, the reverse transfer of endothelial-derived endoperoxides to induce the aggregation of aspirin-treated platelets could not be demonstrated. Aggregation did not occur even when $\mathbf{P G I}_{2}$ synthetase was blocked with tranylcypromine in an attempt to shunt endothelial-derived endoperoxides to the aspirin-treated platelets. Finally, we performed our studies using as substrate both exogenous arachidonic acid and endogenous arachidonic acid released from membrane phospholipid pools by the calcium ionophore A23187. The data using these two sources of arachidonic acid were mutually consistent.

The ability of endothelial cells to utilize prostaglandin endoperoxides generated by platelets activated in their vicinity for $\mathrm{PGI}_{2}$ production was initially suggested by Bunting and associates (6). In these studies, it was found that indomethacin-treated fresh arterial rings, which did not by themselves produce platelet antiaggregatory activity, were able to inhibit platelet aggregation when they were coincubated with PRP (6). Marcus et al. (7), using cultured endothelial cells, provided support for this model with functional platelet aggregation experiments and also by directly demonstrating the utilization of radiolabeled plateletderived endoperoxides by aspirin-treated endothelial cells. However, these investigators did not examine the possibility of reciprocal utilization of endothelial-derived endoperoxides by platelets. Other groups have failed to demonstrate transfer of endoperoxides from platelets to preparations of vascular tissue or cultured cells (8-10), at least without the use of an inhibitor of thromboxane synthetase $(8,10)$, and they have concluded that vascular $\mathrm{PGI}_{2}$ synthesis depends exclusively on endogenously generated substrates. Needleman et al. (8) and Hornstra et al. (9), using intact vascular segments or blood vessel microsomal preparations, found no $\mathrm{PGI}_{2}$ production from plateletderived endoperoxides. Baenziger et al. (10) likewise found no platelet endoperoxide utilization for vascular $\mathbf{P G I}_{2}$ production, determined by bioassay, using aspirin-treated cultured endothelial and smooth muscle cells.

The mechanism of our finding of efficient unidirectional endoperoxide transfer is unclear, but several possibilities must be considered. It has been suggested that prostaglandin endoperoxides are unable to freely penetrate cell membranes (23, 24). Therefore, the unbalanced utilization of endoperoxides by endothelial cells and platelets could be due to differences in the subcellular localization of the endothelial $\mathrm{PGI}_{2}$ synthetase and platelet thromboxane synthetase enzymes. For example, plateletderived endoperoxide could preferentially reach the endothelial $\mathrm{PGI}_{2}$ synthetase if it were an ectoenzyme, as has been postulated (24). However, purified endoperoxides are efficiently converted both by cultured endothelial cells to $\mathrm{PGI}_{2}(25)$ and by platelets to thromboxane $(26,27)$. Furthermore, disruption of the endothelial cells and/or platelets by freeze-thaw lysis (Table III) still did not result in detectable platelet thromboxane formation from endothelial-derived endoperoxides.

Two other possible explanations deserve consideration. Endoperoxides are extremely labile in the presence of plasma proteins, specifically albumin (28). Therefore, it is likely that the transfer of endoperoxides between platelets and endothelial cells requires direct cell-to-cell contact. During the contact of a platelet with an endothelial cell, the large difference in surface area between the two cell types $(29,30)$ would permit proportionally more platelet-derived endoperoxide to penetrate the endothelial cell than in the opposite direction. Most of the endothelialderived endoperoxide would be dissipated into the circulation and avidly bound to plasma proteins. Therefore, the unbalanced transfer of endoperoxides from platelets to endothelial cells may be a function of the relatively greater surface area of the platelet being in contact with the endothelial cell at any given time than vice versa. However, even when we attempted to use an overwhelming ratio of platelets to endothelial cells $(500: 1)$, thus increasing the effective surface area of cell-to-cell contact, $\mathrm{TXB}_{2}$ production from endothelial-derived endoperoxides still could not be demonstrated (Table I, Section $B$ ).

Finally, the apparent unidirectional transfer of endoperoxides may be due to the greater efficiency of endothelial $\mathrm{PGI}_{2}$ synthetase to convert endoperoxides to $\mathrm{PGI}_{2}$ than of platelet thromboxane synthetase to convert exogenous endoperoxides to $\mathrm{TXA}_{2}$. This is supported by data shown in Table II, which indicate that utilization of platelet-generated endoperoxides by endothelial $\mathrm{PGI}_{2}$ synthetase is so efficient that the balance of production of the opposing eicosanoids favors $\mathrm{PGI}_{2}$ over $\mathrm{TXA}_{2}$ at some cell-cell ratios. Furthermore, this transfer of platelet-derived endoperoxides does not occur at the expense of platelet thromboxane production under these experimental conditions. It is possible that platelet endoperoxides are generated in excess of the capacity of thromboxane synthetase to convert them to $\mathrm{TXA}_{2}$. In the absence of endothelial cells, the excess endoperoxides may be rapidly broken down; in the presence of endothelial cells, however, excess endoperoxides are efficiently transferred from the platelets and converted to $\mathrm{PGI}_{2}$ by the efficient $\mathrm{PGI}_{2}$ synthetase.

In summary, we have used different methods to clearly demonstrate the potential for efficient utilization of platelet-derived endoperoxides by endothelial cells for $\mathrm{PGI}_{2}$ production. Furthermore, we have shown that endoperoxide transfer between platelets and endothelial cells is essentially unidirectional under our experimental conditions. The results of this study suggest a model of tightly localized primary hemostasis. Resting intact endothelium may (or may not) tonically produce small amounts 
of $\mathrm{PGI}_{2}$. Adjacent to injured vascular intima, however, where platelet activation occurs and platelet arachidonic acid metabolism is stimulated, endothelial $\mathrm{PGI}_{2}$ production is enhanced by utilization of platelet-derived endoperoxides. Our data suggest that it is possible, in fact, that under physiologic conditions $\mathrm{PGI}_{2}$ synthesis by endothelial cells depends largely on the transfer of endoperoxides from platelets activated at their surface. The resultant platelet inhibitory effect of this process may be amplified by the failure of a reciprocal transfer of endoperoxides to platelets for use in thromboxane production. Thus, amplified $\mathrm{PGI}_{2}$ synthesis by intact endothelium adjacent to a site of vascular injury may serve to efficiently localize platelet plug formation.

\section{Acknowledgments}

The authors are grateful to Dr. Robert I. Handin, Dr. Jordan Pober, and Dr. Susan Rittenhouse for helpful discussions and to Ethel Gordon and Kay W. Case for expert technical assistance with the cell cultures.

This work was supported by National Institutes of Health grants HL-22602 and HL-27465 and by a grant-in-aid from the American Heart Association with funds contributed in part by the Massachusetts Affiliate.

\section{References}

1. Moncada, S., and J. R. Vane. 1979. Arachidonic acid metabolites and the interactions between platelets and blood-vessel walls. $N$. Engl. J. Med. 300:1142-1147.

2. Samuelsson, B. 1979-80. Prostaglandins, thromboxanes, and leukotrienes: formation and biological roles. Harvey Lect. 75:1-40.

3. Marcus, A. J. 1978. The role of lipids in platelet function: with particular reference to the arachidonic acid pathway. J. Lipid Res. 19:793826.

4. Burch, J. W., and P. W. Majerus. 1979. The role of prostaglandins in platelet function. Semin. Hematol. 16:196-207.

5. Weksler, B. B. 1982. Prostacyclin. Prog. Hemostasis Thromb. 6:113-138.

6. Bunting, S., R. Gryglewski, S. Moncada, and J. R. Vane. 1976. Arterial walls generate from prostaglandin endoperoxides a substance (prostaglandin $\mathrm{x}$ ) which relaxes strips of mesenteric and coeliac arteries and inhibits platelet aggregation. Prostaglandins. 12:897-913.

7. Marcus, A. J., B. B. Weksler, E. A. Jaffe, and M. J. Broekman. 1980. Synthesis of prostacyclin from platelet-derived endoperoxides by cultured human endothelial cells. J. Clin. Invest. 66:979-986.

8. Needleman, P., A. Wyche, and A. Raz. 1979. Platelet and blood vessel arachidonate metabolism and interactions. J. Clin. Invest. 63:345349.

9. Hornstra, G., E. Haddeman, and J. A. Don. 1979. Blood platelets do not provide endoperoxides for vascular prostacyclin production. $\mathrm{Na}$ ture (Lond.). 279:66-68.

10. Baenziger, N. L., P. R. Becherer, and P. W. Majerus. 1979. Characterization of prostacyclin synthesis in cultured human arterial smooth muscle cells, venous endothelial cells, and skin fibroblasts. Cell. 16:967-974.

11. Gimbrone, M. A. 1976. Culture of vascular endothelium. Prog. Hemostasis Thromb. 3:1-28.

12. Gimbrone, M. A., E. J. Shefton, and S. A. Cruise. 1978. Isolation and primary culture of endothelial cells from human umbilical vessels. TCA (Tissue Cult. Assoc.) Man. 4:813.

13. Born, G. V. R., and M. J. Cross. 1963. The aggregation of blood platelets. J. Physiol. (Lond.). 168:178-195.
14. Adler, B., M. A. Gimbrone, Jr., A. I. Schafer, and R. I. Handin. 1981. Prostacyclin and $\beta$-adrenergic catecholamines inhibit arachidonate release and $\mathrm{PGI}_{2}$ synthesis by vascular endothelium. Blood. 58:514517.

15. Van Rollins, M., S. H. K. Ho, J. E. Greenwald, M. Alexander, N. J. Dorman, L. K. Wong, and L. A. Horrocks. 1980. Complete separation by high-performance liquid chromatography of metabolites of arachidonic acid from incubation with human and rabbit platelets. Prostaglandins. 20:571-577.

16. Gryglewski, R. J., S. Bunting, S. Moncada, R. J. Flower, and J. R. Vane. 1976. Arterial walls are protected against deposition of platelet thrombi by a substance (prostaglandin $\mathrm{x}$ ) which they make from prostaglandin endoperoxides. Prostaglandins. 12:685-713.

17. Hong, S. L., T. Carty, and D. Deykin. 1980. Tranylcypromine and 15-hydroperoxyarachidonate affect arachidonic acid release in addition to inhibition of prostacyclin synthesis in calf aortic endothelial cells. J. Biol. Chem. 255:9538-9540.

18. Needleman, P. 1979. Prostacyclin in blood vessel-platelet interactions: perspectives and questions. Nature (Lond.). 279:14-15.

19. Goldyne, M. E., and J. D. Stobo. 1982. Human monocytes synthesize eicosanoids from $\mathrm{T}$ lymphocyte-derived arachidonic acid. Prostaglandins. 24:623-630.

20. Jaffe, E. A., and B. B. Weksler. 1979. Recovery of endothelial cell prostacyclin production after inhibition by low doses of aspirin. $J$. Clin. Invest. 63:532-535.

21. Harter, H. R., J. W. Burch, P. W. Majerus, N. Stanford, J. A. Delmez, C. B. Anderson, and C. A. Weerts. 1979. Prevention of thrombosis in patients on hemodialysis by low-dose aspirin. $N$. Engl. J. Med. 301:577-579.

22. Weksler, B. B., S. B. Pett, D. Alonso, R. C. Richter, P. Stelzer, V. Subramanian, K. Tack-Goldman, and W. A. Gray. 1983. Differential inhibition by aspirin of vascular and platelet prostaglandin synthesis in atherosclerotic patients. $N$. Engl. J. Med. 308:800-805.

23. Needleman, P., S. D. Bronson, A. Wyche, M. Sirakoff, and K. C. Nicolaou. 1978. Cardiac and renal prostaglandin $I_{2}$ : biosynthesis and biological effects in isolated perfused rabbit tissues. J. Clin. Invest. 61:839-849.

24. Willems, C., P. G. De Groot, G. A. Pool, M. S. Gonsalvez, W. G. van Aken, and J. A. van Mourik. 1982. Arachidonate metabolism in cultured human vascular endothelial cells: evidence for two prostaglandin synthetic pathways sensitive to acetylsalicylic acid. Biochim. Biophys. Acta. 713:581-588.

25. Marcus, A. J., B. B. Weksler, and E. A. Jaffe. 1978. Enzymatic conversion of prostaglandin endoperoxide $\mathrm{H}_{2}$ and arachidonic acid to prostacyclin by cultured human endothelial cells. J. Biol. Chem. 253:7138-7141.

26. Hamberg, M., J. Svensson, T. Wakabayashi, and B. Samuelsson. 1974. Isolation and structure of two prostaglandin endoperoxides that cause platelet aggregation. Proc. Natl. Acad. Sci. USA. 71:345-349.

27. Hamberg, M., and B. Samuelsson. 1974. Prostaglandin endoperoxides. Novel transformations of arachidonic acid in human platelets. Proc. Natl. Acad. Sci. USA. 71:3400-3404.

28. Hamberg, M., and B. B. Fredholm. 1976. Isomerization of $\mathrm{PGH}_{2}$ into $\mathrm{PGD}_{2}$ in the presence of serum albumin. Biochim. Biophys. Acta. 431:189-193.

29. Thorgeirsson, G., and A. L. Robertson. 1978. The vascular endothelium - pathobiologic significance. Am. J. Pathol. 93:803-848.

30. Baumgartner, H. R., and R. Muggli. 1976. Adhesion and aggregation: morphological demonstration and quantitation in vivo and in vitro. In Platelets in Biology and Pathology. J. L. Gordon, editor. North-Holland Publishing Co., Amsterdam. 23-60. 